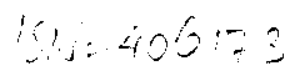

Neth. J. PI. Path. 74 (1968) 184-192

\title{
Studies on Botrytis cinerea in tomatoes. Effect of soil nitrogen level and of methods of deleafing upon the occurrence of B. cinerea under commercial conditions
}

K. Verhoeff

Institute of Phytopathological Research (IPO), Wageningen

Accepted 6 May, 1968

\begin{abstract}
A high nitrogen level in the soil stimulated vegetative development of tomato plants and decreased the incidence of infection by $B$. cinerea. Negative correlations were found between the nitrogen level in the soil on the one hand, and, on the other, the number of stem lesions and the proportion of fruits falling prematurely because of infection by $B$. cinerea at the stalk. In some experiments, similar negative correlations were found between soil nitrogen and the incidence of infected petioles and trusses. Except for two experiments, no correlation was found between the nitrogen level in the soil and the proportion of infected leaves.

Deleafing by breaking off the petiole close to the stem resulted in the lowest incidence of stem lesions as compared with that resulting when the petiole was cut either about $3 \mathrm{~cm}$ or about $5 \mathrm{~cm}$ from the stem.
\end{abstract}

\section{Introduction}

Chemical control of Botrytis cinerea Pers. ex Fr. in commercial glasshouse tomato crops is still impossible; there are no effective fungicides and further, application would be difficult in a crop where picking is done every two or three days. For these reasons, and in order to device other control and disease escape measures, a study was made of the effect of some cultural factors on the incidence of grey mould.

Previous experiments with tomato plants growing in pots had shown a negative correlation between the level of nitrogen in the soil and the growth of $B$. cinerea in the stems after wound inoculation. With a few exceptions, no such a correlation was found with the level of soil potassium (Verhoeff, 1965).

In young tomato plants, Verhoeff (1967) demonstrated that after inoculation of the cut ends of petiole stumps of about $5 \mathrm{~cm}$ length, an abscission layer is formed in the petiole near the stem, causing the stumps to fall before mycelium of $B$. cinerea can grow into the stem. It was suggested that this method of deleafing offered a means of avoiding stem lesions.

Following these observations the effects of nitrogen fertilization and the method of 
deleafing on the occurrence of $B$. cinerea were investigated in commercial unheated tomato crops for three seasons.

\section{Material and methods}

The experiments to test the influence of the nitrogen nutrition were carried out on a number of holdings on various soil types. By adding different amounts of fertilizer before planting, especially ammonium nitrate limestone and sulphate of potash, three or four levels of nitrogen were obtained in the soil. To keep a balanced feeding of the plant, the potassium level was adjusted in proportion with that of nitrogen. This could be done, as potassium has little effect on the spread of $B$. cinerea in the plants (Verhoeff, 1965). At intervals of 2, 3 or 4 weeks, soil samples were taken for chemical analysis and top dressings were given as necessary to keep the nitrogen levels at their initial level. From the time the first infections were seen, counts were made at intervals of 2,3 or 4 weeks, of the number of infected leaves, petioles and trusses per plant and the number of stem lesions per plant. In one experiment the number of fruits with Botrytis spot or "ghost-spot" was counted; in two so-called late tomato crops, the percentage of fruits falling prematurely as a result of infection by $B$. cinerea was determined, this form of grey mould being especially important in late crops.

Except for the two late crops, the number of fruits developing at the first and second truss was counted, to find whether, as expected by growers, a high basic dressing reduced the setting of fruits on these trusses.

In two other experiments three methods and two times of deleafing were compared with reference to the number of stem lesions developing per plant. The petiole was either broken off close to the stem or was cut off at about either 3 or $5 \mathrm{~cm}$ from the stem, each method being used at what growers consider to be "the right time" or "too late".

In all experiments, each treatment had three or four replicates, with a minimum of 12 plants per plot, plants on the margins excluded. Statistical correlations were calculated at the $P<0.05$ level.

\section{Experiments and results}

Light sandy loam. Plants of the variety 'Maascross' were planted at the end of Apri] 1966 in light sandy loam maintained throughout at an average of 45,100 and 165 ppm nitrogen. From the beginning of July until the end of September, the number of infections per plant caused by $B$. cinerea was counted on four occasions, while at every pick, the number of fruits with Botrytis spots was counted. In this experiment only differences in the number of stem lesions between nitrogen levels were significant, the number per plant being the lowest at the highest nitrogen level. The results are given in Fig. 1. There was no direct correlation between the nitrogen level and the proportion of fruits with Botrytis spot, although within plots, a positive correlation was found between spotted fruits and total infections.

Sandy soil. In three experiments on a sandy soil, the nitrogen levels were maintained at an average of 60,150 and $250 \mathrm{ppm}$ nitrogen throughout, and plants of the variety 'Moneymaker', 'Monresist' and 'Yelvic' were planted at the beginning of April 1966, 
Fig. 1. Relation between the nitrogen level of the soil and the number of stem lesions caused by $B$. cinerea in an experiment on a light sandy loam. The average nitrogen content of the soil during the experiment was 45,100 and $165 \mathrm{ppm}$ $\mathbf{N}$ for the low (broken line), medium (dotted line) and high (solid line) levels, respectively.

Fig. 1. Verband tussen het stikstofgehalte van de grond en het aantal stengellesies veroorzaakt door $B$. cinerea in een proef op lichte zavelgrond. Gedurende de proef was het stikstofgehalte van de grond gemiddeld 45, 100 en $165 \mathrm{dpm} N$, respectievelijk voor het lage (streep lijn), het middelmatige (stippel lijn) en het hoge (getrokken lijn) niveau.

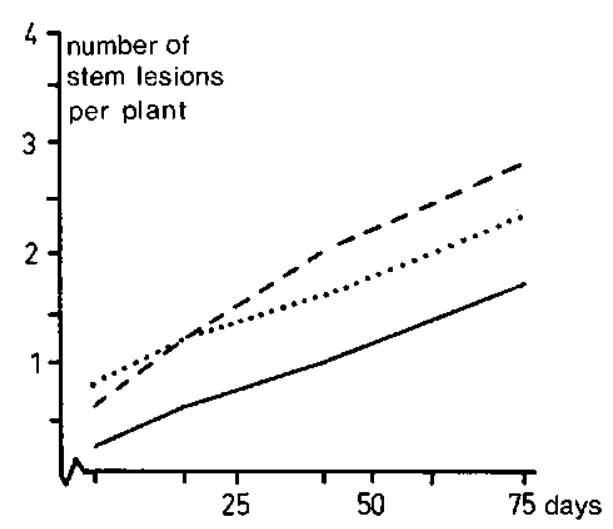

one variety in each experiment. Except on one occasion when there was a significant negative correlation between the number of infected trusses and the nitrogen level of the soil, no significant correlations were found between the nitrogen level of the soil and the number of infected leaves, petioles and trusses. The number of stem lesions per plant from the various plots are given in Table 1 . On holding $A$ the number of stem lesions at the high nitrogen level was significantly different from that at the lower levels at the last count; on holding $B$ this was so at each of the last two counts and at holding $C$ at each of the last three counts.

Peat soil. Similar results were obtained in an experiment on peat soil. Plants of the variety 'Extase', grafted on the corky root resistant rootstock " $K$ " were planted at the end of May 1966 in peat soil maintained at an average of 100, 150 and $200 \mathrm{ppm}$ nitrogen. In this crop hardly any leaf, petiole and truss infections occurred. There was a negative correlation between the nitrogen level of the soil and the number of stem lesions, with 1.5 times more stem lesions per plant at the low level than at the high level at the last count.

Table 1. Relation between the nitrogen level of the soil and the number of stem lesions caused by $B$. cinerea per plant; experiments carried out on three holdings $A, B$ and $C$ on a sandy soil

Date of counting (year 1966)

\begin{tabular}{rccc} 
& \multicolumn{3}{c}{$A$} \\
\cline { 2 - 4 } & 60 & 150 & 250 \\
$28 / 6$ & 1.6 & 1.1 & 1.3 \\
$13 / 7$ & 3.0 & 3.0 & 3.0 \\
$28 / 7$ & 6.0 & 6.0 & 5.0 \\
$23 / 8$ & 8.0 & 6.0 & 6.0 \\
$7 / 9$ & 9.5 & 7.2 & 6.0 \\
$19 / 9$ & - & - & -
\end{tabular}

Nitrogen content of the soil (in ppm)

\begin{tabular}{ccccccc}
\multicolumn{3}{c}{$B$} & & & \multicolumn{3}{c}{$C$} \\
\cline { 5 - 7 } 60 & 150 & 250 & & 60 & 150 & 250 \\
& & & & & & \\
0.7 & 0.7 & 0.7 & & 0.5 & 0.5 & 0.6 \\
1.2 & 1.3 & 1.6 & & 1.0 & 1.0 & 0.9 \\
2.0 & 2.5 & 2.2 & & 1.5 & 1.2 & 0.9 \\
2.3 & 2.5 & 2.3 & & 1.7 & 1.7 & 1.0 \\
4.0 & 3.8 & 2.7 & & 2.4 & 2.1 & 1.0 \\
4.3 & 3.9 & 2.7 & & - & - & -
\end{tabular}

Tabel 1. Verband tussen het stikstofgehalte van de grond en het aantal door $B$. cinerea veroorzaakte stengellesies per plant; de proeven werden uitgevoerd op drie bedrijven $A, B$ en $C$ gelegen op zandgrond 
Sea clay soil. Two experiments were carried out on a sea clay soil, in each of which four levels of nitrogen were maintained, the soil containing an average of 120,180 , 265 and $345 \mathrm{ppm}$ nitrogen throughout the season in experiment 1 and an average of $65,120,245$ and $300 \mathrm{ppm}$ nitrogen in experiment 2. Plants of the variety 'Moneyrest', grafted on the corky root resistant rootstock " $\mathrm{K}$ " were planted in the beginning of April 1967. In the first experiment, where deleafing was done by cutting the petiole at about $3-5 \mathrm{~cm}$ from the stem, the number of infections by $B$. cinerea was quite high. Except for on one occasion, when the number of infected leaves at the lowest nitrogen level was four times that at the highest level, no significant differences were found between treatments in the number of infected leaves per plant. The number of infected petioles and infected trusses was the highest at the lowest nitrogen level during most of the growing season, with significant differences between the two lower and the two higher nitrogen levels at the two last counts. The numbers of stem lesions per plant at the various levels are given in Table 2 . The negative correlation between the nitrogen level of the soil and the number of stem lesions is evident. In the second experiment, the number of infections was rather low. At one count, the number of infected leaves per plant was significantly higher at the highest nitrogen level; all other results were similar to those of the previous experiment.

In two experiments in 1966 on sea clay soil having an average content of 70,150 and $200 \mathrm{ppm}$ nitrogen throughout the season, no significant differences were found between treatments in the number of infections.

In all the experiments described above, there was no difference between treatments in the number of fruits developing on the first and the second trusses.

River clay soil. On two holdings on a river clay soil counts of infections were made in fertilizer trials of the Institute for Soil Fertility (reported by Roorda van Eysinga, 1966). In 1965 , levels of nitrogen in the soil were maintained at about 25,60 or 145 ppm during an experiment with a so-called late tomato crop, plants of the variety 'Moneymaker' having been planted at the beginning of May. Three counts were made during September and October and some of the results are given in Table 3. At each count, there were negative correlations between the nitrogen level of the soil and the number

Table 2. Relation between the nitrogen level of the soil and the number of stem lesions caused by $B$. cinerea per plant in an experiment on a sea clay soil

Date of counting (year 1967)

$13 / 6$
$27 / 6$
$11 / 7$
$25 / 7$
$10 / 8$
$24 / 8$
$8 / 9$

\begin{tabular}{rr}
\multicolumn{2}{c}{ Nitrogen content } \\
\hline 150 & 180 \\
$(a)$ & $(b)$ \\
0.2 & 0.1 \\
0.5 & 0.3 \\
2.6 & 1.5 \\
6.3 & 4.3 \\
9.5 & 6.5 \\
11.8 & 9.1 \\
13.4 & 12.5
\end{tabular}

Tabel 2. Verband tussen het stikstofgehatte van de grond en het aantal door $B$. cinerea veroorzaakte stengellesies per plant, in een proef genomen op zeekleigrond
Differences significant

$(P<0.05)$ between

$$
\begin{aligned}
& a \text { and } b, c, d \\
& a \text { and } b, c, d \\
& a \text { and } b, c, d \\
& a \text { and } b, d \text { and } c \\
& a \text { and } b \text { and } c, d \\
& a \text { and } b \text { and } c, d \\
& a, b \text { and } c, d
\end{aligned}
$$


Table 3. Relation between the nitrogen level of the soil and the number of stem lesions and the percentages of fruits falling prematurely following stalk infection by $B$. cinerea in two late tomato crops on a river clay soil

Nitrogen content of the soil (in ppm)

\begin{tabular}{|c|c|c|c|c|c|c|c|c|c|c|}
\hline \multirow[t]{2}{*}{ Exp. 1} & \multirow[t]{2}{*}{ Exp. 2} & \multicolumn{3}{|c|}{ Experiment 1} & \multicolumn{4}{|c|}{ Experiment 2} & \multicolumn{2}{|c|}{$\begin{array}{l}\text { total yela per treat- } \\
\text { ment }\end{array}$} \\
\hline & & $21 / 9$ & $5 / 10$ & $19 / 10$ & $3 / 8$ & $17 / 8$ & $1 / 9$ & $21 / 9$ & Exp. I & Exp. 2 \\
\hline 25 & 25 & 2.4 & 3.4 & 4.7 & 0.2 & 1.4 & 2.5 & 6.2 & 5.0 & 9.8 \\
\hline 60 & 50 & 1.1 & 2.2 & 3.7 & 0.2 & 0.8 & 1.9 & 3.9 & 3.7 & 6.3 \\
\hline 135 & 110 & 0.9 & 1.6 & 2.9 & 0.2 & 0.6 & 1.3 & 3.3 & 3.5 & 5.3 \\
\hline
\end{tabular}

Fruits fallen prematurely expressed as percentages of the total yield per treat-

Tabel 3. Verband tussen het stikstofgehalte van de grond en het aantal door B. cinerea veroorzaakte stengellesies en het percentage vruchten, voortijdig afgevallen als gevolg van ontwikkeling van B. cinerea in de vruchtsteel; de proeven werden genomen in twee late tomateteelten op rivierkleigrond.

of infected petioles and trusses and also between nitrogen level and the number of stem lesions. Further, the proportion of fruits, falling prematurely following stalk infection by $B$. cinerea was the lowest at the highest nitrogen level, the differences between treatments being significant. There was a positive correlation between the nitrogen level of the soil and the number of infected leaves per plant, with about 2.5 times more at the higher than at the lower nitrogen levels.

In the second experiment, nitrogen levels were maintained at an average of 25,50 or $110 \mathrm{ppm}$ nitrogen throughout, plants of the variety 'Eurocross' having been planted in May 1966. There were no significant differences between treatments in the number of infected leaves and petioles per plant, but the number of stem lesions per plant was significantly different at all but the first count, these being least at the highest nitrogen level. The proportion of fruits, falling prematurely because of infection of the stalk by $B$. cinerea, was also significant different at the three nitrogen levels, with the highest proportion at the lowest level. Some of the results of this experiment are also given in Table 3.

In these two experiments, the three nitrogen levels of the soil were combined with three potassium levels, but no effect of the potassium level on the occurrence of $B$. cinerea was found.

Methods of deleafing. In each of two experiments, three methods of deleafing, combined with two times of deleafing were compared in plants of the variety 'Maascross' planted at the end of April 1966. In the first experiment stem lesions were counted five times. The results of the three deleafing methods are given in Fig. 2. The number of stem lesions where deleafing was done "too late" were slightly higher than those, where deleafing was done at the "normal time", but the differences were not significant. In the other experiment four counts were made of the number of stem lesions, with similar results as in the first experiment. 


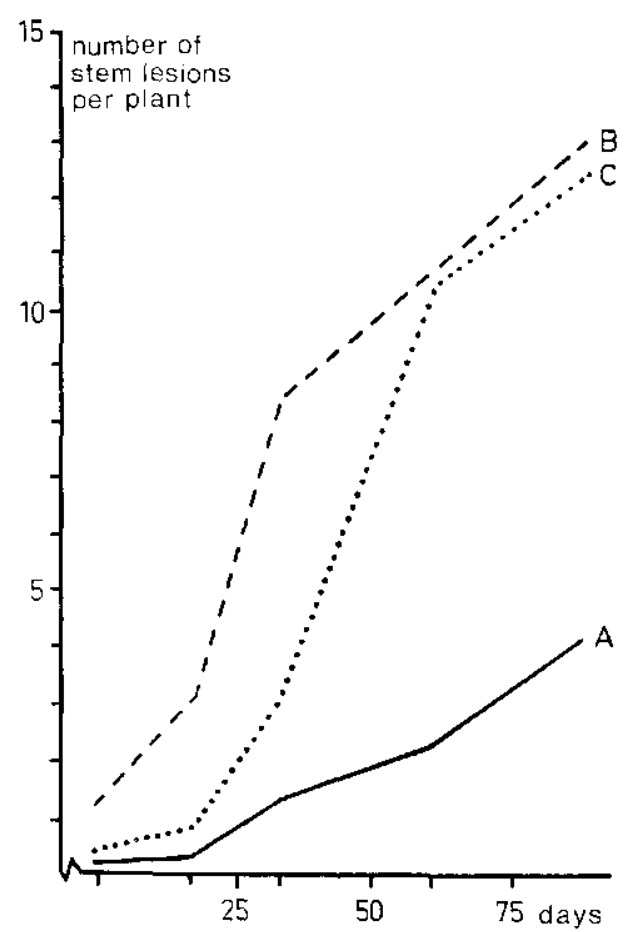

Fig. 2. Effect of the method of deleafing on the occurrence of stem lesions, caused by $B$. cinerea. Deleafing was done at the "normal time".

$\mathrm{A}=$ breaking off the petiole close to the stem $B=$ cutting off the petiole at about $3 \mathrm{~cm}$ from the stem

$\mathrm{C}==$ cutting off the petiole at about $5 \mathrm{~cm}$ from the stem

Fig. 2. Het effect van de manier waarop bladeren worden verwijderd op het optreden van stengellesies, veroorzaakt door B. cinerea. Het verwijderen der bladeren geschiedde op de "normale" tijd.

$A=$ afbreken van de bladsteel vlak bij de stengel $B=$ afsnijden van de bladsteel op $3 \mathrm{~cm}$ afstand van de stengel

$C=$ afsnijden van de bladsteel op $5 \mathrm{~cm}$ afstand van de stengel

\section{Discussion}

These experiments, carried out under commercial conditions, showed the same relationship as those obtained with plants grown in pots; the negative correlation between the soil nitrogen level and the incidence of stem lesions caused by $B$. cinerea is again evident. The same negative correlation was found between soil nitrogen level and the percentages of fruits falling prematurely after infection at the stalk, and also, though to a lesser extent, between soil nitrogen and the number of infected petioles and trusses. The effect of soil nitrogen on leaf infection is not quite clear, as in some experiments there was more infection at high nitrogen levels and in others, less infection. However, infected leaves are often taken away when the grower is deleafing the plants, and if this had been done just before a count, an abnormally low number of infected leaves would have been obtained, where as on holdings where there had been a long interval between the last deleafing and the count, the incidence would have been apparently high. No conclusion on the effect of soil nitrogen on leaf infection can be drawn therefore, but it is interesting to note that Hobbs and Waters (1964) found a positive correlation between the nitrogen level of the soil and the infection of chrysanthemum leaves by $B$. cinerea.

Despite the fact that high soil nitrogen stimulates vegetative growth, resulting in favourable microclimatic conditions for the development of $B$. cinerea, there is a negative correlation between these two factors, except sometimes in the case of leaf intection. Stall et al. (1965), though working with various phosphorus and calcium levels, 
also found no increase in the development of $B$. cinerea in plots where the vegetative growth of the tomato plants was stimulated.

Soil nitrogen level has no direct effect on the number of fruits with Botrytis spot but there was an indirect effect, as in plots with many infections elsewhere on the plant, the number of fruits with Botrytis spot was also high. Similarly, Roorda van Eysinga (1966) found a negative correlation between the nitrogen level of the soil and the number of tomato fruits infected with Phytophthora infestans (Mont.) de Bary.

The results of the experiments on the effect of the method of deleafing upon the number of stem lesions are different from those obtained with young, in pot growing plants in earlier experiments (Verhoeff, 1967). Apparently, the xylem cylinder prevents complete abscission in the petioles with larger diameters, since no cambial activity takes place in the xylem (Verhoeff, 1967). The stumps remain attached to the stem, providing excellent starting points for stem infections by $\boldsymbol{B}$. cinerea. When deleafing is done by breaking off the petiole close to the stem, the lowest number of stem lesions occurs and this decreases with higher nitrogen levels of the soil. When petiole stumps are left at deleafing, this negative correlation can be explained by the fact that the growth of the mycelium of the fungus through petiole tissue is slower at higher soil nitrogen levels. It does not, however, explain the lower number of stem lesions when deleafing is done by breaking off the petiole close to the stem; a saprophytical base for the growth of the fungus is not provided as in the case of the dying petiole stumps, although lesions can develop after conidia have been sucked into the xylem vessels of a fresh leaf scar, as was demonstrated by Wilson (1963).

Verhoeff (1967) showed that infected petiole stumps frequently became detached earlier than uninfected ones because of more rapid abscission-zone formation; a similar mechanism can also explain the higher percentages of fruits falling prematurely as the result of infections, which occur at the lower nitrogen levels. An abscission layer forms in the fruit stalk in response to growth of the fungus via the calyx towards the fruit stalk and when this growth is retarded at high soil nitrogen levels, abscission is delayed:

The experiments described clearly demonstrate two things: (1) Higher nitrogen levels in the soil decrease the number of infections, caused by $B$. cinerea on all parts of the tomato plants, except perhaps on the leaves, and (2) Of all methods of deleafing, that of breaking off the petioles close to the stem results in the lowest incidence of stem lesions. While this method of deleafing is already the standard procedure used by growers, further improvement in disease escape would be achieved if more nitrogen were to be applied, especially as this also frequently results in a higher yield and a better quality of fruit, as has been shown by Roorda van Eysinga (1969). Further, there is no supporting evidence for the view that high nitrogen reduces fruit set in the first and second trusses.

\section{Acknowledgments}

The author is very much indebted to Miss T. Valstar, Mr. L. Weber and Mr. J. P. van Bergenhenegouwen for technical assistance and to Mr. B. J. van der Kaay for statistical analyses (Horticultural Research and Experiment Station, Naaldwijk) and to Dr W. R. Jarvis (Scottish Horticultural Research Institute) for reading the manuscript. 


\section{Samenvatting}

Botrytis cinerea in tomaten. De invloed van de stikstofbemesting en van het op verschillende manieren verwijderen van bladeren op het optreden van $B$. cinerea onder praktijkomstandigheden

Bestrijding van Botrytis cinerea is bij in kassen geteelde tomaten niet mogelijk; er is nog geen effectief bestrijdingsmiddel bekend; bovendien zal in een gewas waarvan vanaf het moment waarop de eerste vruchten rijp zijn, om de twee of drie dagen wordt geoogst, toepassing van een fungicide moeilijk zijn. Om deze redenen is gezocht naar andere mogelijkheden om de ziekte tegen te gaan. Bij eerder genomen proeven, uitgevoerd met in potten groeiende tomateplanten, bleek een negatieve correlatie te bestaan tussen het stikstofgehalte in de grond en de uitbreiding van $B$. cinerea in de stengels (Verhoeff, 1965).

Met jonge planten kon vervolgens aangetoond worden, dat na het afsnijden van de bladeren op enige afstand van de stengel, de bladsteelstomp snel wordt afgestoten als het mycelium van $B$. cinerea zich hierin ontwikkelt. Dit afstoten gebeurt vóórdat het mycelium de stengel heeft bereikt (Verhoeff, 1967).

Zowel de invloed van de bemesting als de wijze van bladverwijderen is nader onderzocht in een aantal, onder praktijkomstandigheden genomen proeven met tomaten, geteeld in koude kassen. Met behulp van verschillende meststoffen, met name van kalkammonsalpeter en kaliumsulfaat werden voor het planten drie of vier bemestingsniveaus in de grond aangebracht. Aan de hand van grondanalyses zijn deze niveaus tijdens de teelt zo constant mogelijk gehouden. In een op lichte zavelgrond genomen proef werden significante verschillen gevonden tussen het aantal stengelaantastingen bij de drie stikstofniveaus (Fig. 1). Ook in een aantal op zandgrond genomen proeven was tegen het einde van de teelt een negative correlatie tussen het stikstofniveau en het aantal stengelaantastingen waar te nemen (Tabel 1); in een proef op veengrond werden overeenkomstige resultaten verkregen. In een tweetal, op zware zavel uitgevoerde proeven traden niet alleen grotere verschillen op in de aantallen stengelaantastingen bij de verschillende bemestingsniveaus (Tabel 2), maar ook was er een negatief verband tussen het aantal aangetaste bladstelen en trossen en het bemestingsniveau. Verder werd in de ene proef eenmaal een betrouwbare positieve in de andere eenmaal een betrouwbare negatieve correlatie gevonden tussen het aantal aangetaste bladschijven en het bemestingsniveau.

In een op rivierklei genomen proef met een zogenaamde late tomateteelt, waren duidelijk negatieve correlaties tussen het bemestingsniveau en het aantal bladsteel-, stengel- en trosaantastingen waar te nemen. Bovendien bleek een dergelijke correlatie te bestaan met het aantal vruchten, afgevallen als gevolg van ontwikkeling van $B$. cinerea in de kelkbladeren en in de vruchtsteel (Tabel 3). In een andere, op rivierklei genomen proef, werden soortgelijke uitkomsten verkregen wat betreft de stengelaantastingen en de vruchtval (Tabel 3). Er konden echter geen betrouwbare verschillen worden gevonden tussen de aantallen aangetaste bladeren en trossen bij de verschillende bemestingsniveaus. Uitgezonderd bij deze laatste twee proeven, waar de waarnemingen niet werden verricht, kon in geen van de overige proeven enige invloed van de bemesting op het aantal vruchten aan de eerste en tweede tros worden gevonden, zoals door kwekers werd verondersteld. 
In de op lichte zandgrond genomen proef, werd ook het aantal vruchten met Botrytis"stip" geteld. Er bleek geen verband te bestaan tussen het bemestingsniveau en het aantal vruchten met "stip". Wel was er een positieve correlatie tussen het totaal aantal aanwezige infecties van $B$. cinerea per object en het aantal vruchten met "stip". In twee proeven zijn drie manieren van bladverwijderen met elkaar vergeleken, te weten het afsnijden van de bladsteel op ongeveer 3 of op ongeveer $5 \mathrm{~cm}$ van de stengel en het afbreken van de bladsteel nabij de stengel. Deze laatste methode is de in de praktijk gebruikelijke. De drie methoden werden toegepast op wat kwekers beschouwen als het "juiste tijdstip" en "te laat". Het geringste aantal stengellesies ontwikkelde zich bij die planten, waarvan de bladeren waren weggenomen door de bladstelen nabij de stengel af te breken (Fig. 2). Het "te laat" verwijderen leidde tot een hoger aantal stengellesies maar de verschillen met de behandelingen op het "juiste tijdstip" waren niet betrouwbaar. Het is dus duidelijk gebleken, dat hogere stikstofniveaus in de grond tot verminderde infecties van $B$. cinerea leiden op alle delen van de plant, uitgezonderd misschien de bladeren. Bovendien is aangetoond, dat de in de praktijk gebruikelijke methode van bladverwijderen beter is dan die, waarbij de bladstelen op enige afstand van de stengel worden afgesneden.

\section{References}

Hobbs, E. L. and Waters, E. W., 1964. Influence of nitrogen and potassium on susceptibility of Chrysanthemum morifolium to Botrytis cinerea. Phytopathology 54:674-676.

Roorda van Eysinga, J. P. N. L., 1966. Mineral fertilization, yield and quality of vegetables. Int. Potash Inst. Bern, Proc. Brussels Congress.

Roorda van Eysinga, J. P. N. L., 1969. Fertilization of tomatoes with nitrogen. (In preparation).

Stall, R. E., Hortenstine, C. C. and Iley, J. R., 1965. Incidence of Botrytis Gray Mold of tomato in relation to a calcium-phosphorus balance. Phytopathology 55:447-449.

Verhoeff, K., 1965. Studies on Botrytis cinerea in tomatoes. Mycelial development in plants growing in soil with various nutrient levels, as well as in internodes of different age. Neth. J. Pl. Path. $71: 167-$ 175.

Verhoeff, K., 1967. Studies on Botrytis cinerea in tomatoes. Influence of methods of deleafing on the occurrence of stem lesions. Neth. J. PI. Path. 73:117-120.

Wilson, A. R., 1963. Grey Mould of tomato. Etiology of stem infection by Botrytis cinerea. Rep. Scott. hort. Res. Inst. 1962-1963:79-81. 